University of Nebraska - Lincoln

DigitalCommons@University of Nebraska - Lincoln

Publications from USDA-ARS / UNL Faculty

U.S. Department of Agriculture: Agricultural

Research Service, Lincoln, Nebraska

2011

Evaluation of Waxy Grain Sorghum for Ethanol Production

Shuping Yan

Kansas State University

Xiaorong Wu

Kansas State University

Scott R. Bean

United States Department of Agriculture

Jeffery F. Pedersen

USDA-ARS, Grain, Forage, and Bioenergy Research Unit, jpedersen1@unl.edu

Tesfaye Tesso

Kansas State University

See next page for additional authors

Follow this and additional works at: https://digitalcommons.unl.edu/usdaarsfacpub

Part of the Agricultural Science Commons

Yan, Shuping; Wu, Xiaorong; Bean, Scott R.; Pedersen, Jeffery F.; Tesso, Tesfaye; Chen, Yuanhong; and Wang, Donghai, "Evaluation of Waxy Grain Sorghum for Ethanol Production" (2011). Publications from USDA-ARS / UNL Faculty. 942.

https://digitalcommons.unl.edu/usdaarsfacpub/942

This Article is brought to you for free and open access by the U.S. Department of Agriculture: Agricultural Research Service, Lincoln, Nebraska at DigitalCommons@University of Nebraska - Lincoln. It has been accepted for inclusion in Publications from USDA-ARS / UNL Faculty by an authorized administrator of DigitalCommons@University of Nebraska - Lincoln. 


\section{Authors}

Shuping Yan, Xiaorong Wu, Scott R. Bean, Jeffery F. Pedersen, Tesfaye Tesso, Yuanhong Chen, and Donghai Wang 


\title{
Evaluation of Waxy Grain Sorghum for Ethanol Production ${ }^{1}$
}

\author{
Shuping Yan, ${ }^{2,3}$ Xiaorong Wu, ${ }^{2}$ Scott R. Bean, ${ }^{4}$ Jeffery F. Pedersen, ${ }^{5}$ Tesfaye Tesso,${ }^{6}$ \\ Yuanhong R. Chen, ${ }^{4}$ and Donghai Wang ${ }^{2,7}$
}

The objective of this research was to investigate the fermentation performance of waxy grain sorghum for ethanol production. Twenty-five waxy grain sorghum varieties were evaluated with a laboratory dry-grind procedure. Total starch and amylose contents were measured following colorimetric procedures. Total starch and amylose contents ranged from 65.4 to $76.3 \%$ and from 5.5 to $7.3 \%$, respectively. Fermentation efficiencies were in the range of $86.0-92.2 \%$, corresponding to ethanol yields of 2.61-3.03 gallons/bushel. The advantages of using waxy sorghums for ethanol production include easier gelatinization and low viscosity during liquefaction, higher starch and protein digestibility, higher free amino nitrogen (FAN) content, and shorter fermentation times. The results showed a strong linear relationship between FAN content and fermentation rate. Fermentation rate increased as FAN content increased, especially during the first $30 \mathrm{hr}$ of fermentation $\left(R^{2}=0.90\right)$. Total starch content in distillers dried grains with solubles (DDGS) was less than $1 \%$ for all waxy varieties.
Unlike wheat, corn, and rice, grain sorghum is a starch-rich cereal that can be grown economically in the semiarid regions of the world. In the United States, sorghum is the second-ranking feed grain and is cultivated primarily in the Great Plains, including the Midwest and the Southwest. Although it is primarily used as feed in the United States, grain sorghum has been reported in wide uses such as wallboard, fermented beverages, traditional foods (porridges and flat breads), and conventional pan bread for gluten-free markets (Owuama 1997; Rooney and SernaSaldivar 2000; Schober et al 2005; Taylor et al 2006). Sorghum utilization by the ethanol industry has been growing in the United States in recent years (RFA 2007; Sarath et al 2008). Currently, about $95 \%$ of U.S. fuel ethanol is produced from corn and $\approx 4 \%$ is from sorghum grain, which uses $30-35 \%$ of the total sorghum production in the United States (Kubecka 2011; USDA-NASS 2011). Sorghum could make a larger contribution to the nation's fuel ethanol requirements (Farrell et al 2006; Rooney et al 2007; Wu et al 2007).

Overall, sorghum composition is similar to corn. Starch is the major grain component, followed by protein. Most sorghum starches contain 20-30\% amylose and 70-80\% amylopectin, but waxy and heterowaxy sorghums contain 0-15\% amylose and 85$100 \%$ amylopectin (Rooney and Serna-Saldivar 2000). Starch content in grains is a good predictor of ethanol yield (Lacerenza et al 2008; Zhao et al 2009). The presence or absence of amylose may influence ethanol yield and conversion efficiency. Wu et al (2007) reported that low amylose content in sorghum grain may be associated with increased ethanol conversion efficiency. One of

\footnotetext{
*The $e$-Xtra logo stands for "electronic extra" and indicates that Figure 1 appears in color online.

${ }^{\mathrm{I}}$ Contribution number 11-327-J from the Kansas Agricultural Experiment Station, Manhattan, KS 66506

${ }^{2}$ Department of Biological and Agricultural Engineering, Kansas State University, Manhattan, KS 66506

${ }^{3}$ Present address: C. W. Brabender Instrument, Inc., 50 E. Wesley Street, S. Hackensack, NJ 07606.

${ }^{4}$ U.S. Department of Agriculture, Agricultural Research Service (USDA-ARS), Center for Grain and Animal Health, Manhattan, KS 66502.

${ }^{5}$ USDA-ARS, Grain, Forage, and Bioenergy Research Unit, Lincoln, NE 68583. Names are necessary to report factually on available data; however, USDA neither guarantees nor warrants the standard of the product, and the use of the name by the USDA implies no approval of the product to the exclusion of others that may also be suitable.

${ }^{6}$ Department of Agronomy, Kansas State University, Manhattan, KS 66506.

${ }^{7}$ Corresponding author. Phone: (785) 532-2919. Fax: (785) 532-5825. E-mail: dwang@ksu.edu
}

the aims for this study, which was conducted on 25 varieties of waxy grain sorghum, was to investigate further whether ethanol yield and fermentation efficiency were influenced by the contents of amylose and amylopectin in waxy grain sorghums.

Both ethanol yield and fermentation efficiency have been studied to evaluate the performance of grain sorghum in ethanol production (Wu et al 2007). Recent research has shown that key factors affecting the ethanol yield from grain sorghum include grain hardness and particle size, starch content and digestibility, amount and types of phenolic compounds present in sorghum, amount of amylose, formation of amylose-lipid complexes during mashing (Wu et al 2007; Wang et al 2008; Yan et al 2009), level of extractable proteins, protein-starch interaction, and mash viscosity (Zhao et al 2008). Sorghum as a raw material can be converted to ethanol with a wide range of efficiency (Wu et al 2007).

Currently, almost $100 \%$ of industrial ethanol is produced by yeast from starch-rich or sugar-rich biomass. The availability of yeast food is vital to yeast growth and its efficiency in converting fermentable sugars into ethanol during fermentation. As such, most yeast fermentation systems need nutrient supplementation. Yeast uptakes not only fermentable sugars for ethanol production but also nutrients (amino acids, minerals, and vitamins) for its own growth and functional maintenance (e.g., levels of invertase and permeases, which are responsible for sugar transportation and conversion). Free amino nitrogen (FAN) is an essential nutrient for yeast growth during fermentation (Pickerell 1986; Taylor and Boyd 1986). Protein is the second major component in grain sorghum. Protein degradation could provide nitrogen for yeast growth during fermentation. Recent research has found that ethanol yield and conversion efficiency significantly increased as FAN increased in laboratory-germinated and field-sprouted grain sorghum (Yan et al 2009, 2010). Yeast can only utilize FAN and short peptides, not large intact proteins. Much research has been conducted on the effects of protein and protein digestibility on ethanol fermentation of various cereal grains such as wheat and barley (Lacerenza et al 2008), sorghum and maize (Pérez-Carrillo and Serna-Saldívar 2007; Pérez-Carrillo et al 2008; Zhao et al 2008), and different varieties of maize (Wu 1989; Wang et al 2005), but little research has been conducted on the effect of FAN on the conversion efficiency of sorghum varieties in ethanol fermentation.

Sorghum is a large, variable genus with many cultivars. Many varieties of sorghum exist, and more are being developed through plant breeding to select and concentrate desired characteristics in new varieties for food and feed applications (Rooney and SernaSaldivar 2000; Mace and Jordan 2010). We believe genetically improving the quality of grain sorghum for ethanol production could increase the utilization of sorghum for ethanol production 
in the near future. The main objective of this research was to investigate the fermentation performance of waxy grain sorghum for ethanol production.

\section{MATERIALS AND METHODS}

\section{Grain Sorghum}

Twenty-five waxy grain sorghum varieties were obtained from the U.S. Department of Agriculture, Agricultural Research Service (USDA-ARS), Grain, Forage, and Bioenergy Research Unit (Lincoln, NE). The origin of these waxy varieties was from 10 different countries around the world, and the seeds of these accessions were increased by the USDA-ARS in Nebraska (Pedersen et al 2007). Detailed sample information is listed in Table I. The samples were manually cleaned by removing plant debris and foreign materials and then were ground to flour with a UDY cyclone sample mill (Fort Collins, $\mathrm{CO}$ ) with a $1.0 \mathrm{~mm}$ screen.

\section{Preparation of Mashes and Inoculation of Yeast}

Liquozyme SC DC, a heat-stable $\alpha$-amylase from Bacillus licheniformis was used for liquefaction (Novozyme, Franklinton, $\mathrm{NC}$ ). The listed enzyme activity was $240 \mathrm{KNU} / \mathrm{g}$ (one kilo Novo unit, or KNU, is the amount of enzyme that breaks down $5.26 \mathrm{~g}$ of starch per hour at Novozyme's standard method for determination of $\alpha$-amylase). Spirizyme Fuel (Novozyme), an amyloglucosidase from Aspergillus niger, was used for saccharification. Its listed enzyme activity was $750 \mathrm{AGU} / \mathrm{g}$ (one AGU is the amount of enzyme that hydrolyzes $1 \mu \mathrm{mol}$ of maltose per minute under specified conditions). Ethanol red active dry yeast (Saccharomyces cerevisiae) from Fermentis (Milwaukee, WI) was used for simultaneous saccharification and fermentation (SSF). Before inoculation, dry yeast $\left(\approx 2 \times 10^{10}\right.$ live cells per gram) was activated by adding $1.0 \mathrm{~g}$ of dry yeast cells into $19 \mathrm{~mL}$ of preculture broth (containing $20 \mathrm{~g}$ of glucose, $5.0 \mathrm{~g}$ of peptone, $3.0 \mathrm{~g}$ of yeast extracts, $1.0 \mathrm{~g}$ of $\mathrm{KH}_{2} \mathrm{PO}_{4}$, and $0.5 \mathrm{~g}$ of $\mathrm{MgSO}_{4} \cdot \mathrm{H}_{2} \mathrm{O}$ per liter) and shaking at $200 \mathrm{rpm}$ in a $38^{\circ} \mathrm{C}$ incubator for $30 \mathrm{~min}$. The activated yeast culture had a cell concentration of roughly $1 \times 10^{9}$ cells $/ \mathrm{mL}$.

Thirty grams (db) of sorghum flour for each sample was dispersed in $100 \mathrm{~mL}$ of water (containing $0.1 \mathrm{~g}$ of $\mathrm{KH}_{2} \mathrm{PO}_{4}$ and preheated to about $60^{\circ} \mathrm{C}$ ) in a $250 \mathrm{~mL}$ Erlenmeyer flask. Twenty microliters of high-temperature $\alpha$-amylase (Liquozyme, 240 $\mathrm{KNU} / \mathrm{g}$ ) was added into the sorghum flour slurry. The flasks were transferred to a $70^{\circ} \mathrm{C}$ water-bath shaker operating at $170 \mathrm{rpm}$. The water-bath temperature was gradually increased from $70^{\circ} \mathrm{C}$ to $85^{\circ} \mathrm{C}$ over a $30 \mathrm{~min}$ period. The liquefaction process continued at $85^{\circ} \mathrm{C}$ for another $60 \mathrm{~min}$. The flasks were then removed from the water-bath shaker and cooled to room temperature. Materials sticking to the inner surface of each flask were scraped back into the mash with a spatula, and then the inner surface was rinsed with 2-3 mL of distilled water with a fine-tipped polyethylene transfer pipette. The $\mathrm{pH}$ of the mashes was adjusted to $4.2-4.3$ with $2 N \mathrm{HCl}$. After $\mathrm{pH}$ adjustment, $100 \mu \mathrm{L}$ of amyloglucosidase (Spirizyme Fuel), $1 \mathrm{~mL}$ of activated yeast broth, and $0.3 \mathrm{~g}$ of yeast extract ( $1 \mathrm{~mL}$ of freshly prepared $30 \%$ yeast extract solution) were added to each flask. The inoculated flasks were then sealed with S-shaped airlocks and transferred to an incubator shaker for SSF. All samples were run in duplicate.

\section{Fermentation and Distillation}

Ethanol fermentation was conducted at $30^{\circ} \mathrm{C}$ in an incubator shaker (12400, New Brunswick Scientific, Edison, NJ) operating at $150 \mathrm{rpm}$ for $72 \mathrm{hr}$. The fermentation process was monitored by measuring the weight loss from evolution of carbon dioxide $\left(\mathrm{CO}_{2}\right)$ during fermentation. The weight loss was related to ethanol yield during fermentation $\left(\mathrm{C}_{6} \mathrm{H}_{12} \mathrm{O}_{6} \rightarrow 2 \mathrm{C}_{2} \mathrm{H}_{6} \mathrm{O}+2 \mathrm{CO}_{2}{ }^{\uparrow}\right)$. The ratio of ethanol to carbon dioxide is theoretically $46: 44$.

After $72 \mathrm{hr}$ of fermentation, finished mash in each $250 \mathrm{~mL}$ flask was entirely transferred to a $500 \mathrm{~mL}$ distillation flask, and the Erlenmeyer flask was washed four times with $100 \mathrm{~mL}(25$ $\mathrm{mL} \times 4$ ) of distilled water. Two drops of antifoam agent 204 were added into the distillation mash to prevent foaming during distillation. The contents were distilled in a distillation unit, and the distillates were collected into a $100 \mathrm{~mL}$ volumetric flask that was immersed in ice water. When the distillates in the volumetric flask approaching the $100 \mathrm{~mL}$ mark $(<0.5 \mathrm{~mL}$ to the mark), the volumetric flask was removed from the distillation unit and the distillation process was stopped. The distillates in the volumetric flask were equilibrated for a few hours in a $25^{\circ} \mathrm{C}$ water bath and

TABLE I

Sample Information, Chemical Composition $(\%, \mathrm{db})$, and Fermentation Efficiency (\%) of Waxy Sorghums ${ }^{\mathrm{a}}$

\begin{tabular}{|c|c|c|c|c|c|c|c|c|c|c|c|c|}
\hline Accession No. & Local Name & Origin & GBSS & Allele & Amylose & Starch & Protein & Fat & Fiber & Ash & Efficiency & Tannin \\
\hline PI220636 & Nai-Shaker & Afghanistan & No & $w x^{\mathrm{a}}$ & $6.6 \pm 0.57$ & 66.80 & 14.46 & 6.56 & 1.56 & 2.64 & 88.4 & + \\
\hline PI23231 & Brown Kaoliang & China & Yes & $w x^{\mathrm{b}}$ & $6.8 \pm 0.38$ & 67.46 & 13.75 & 5.02 & 2.22 & 2.01 & 89.4 & + \\
\hline PI548008 & Huang Ke Jiao & China & No & $w x^{\mathrm{a}}$ & $5.5 \pm 0.70$ & 68.74 & 15.09 & 4.98 & 1.52 & 2.54 & 87.7 & + \\
\hline PI563576 & LV 129 & China & No & $w x^{\mathrm{a}}$ & $6.9 \pm 0.87$ & 68.38 & 15.80 & 5.70 & 1.59 & 2.38 & 89.8 & - \\
\hline PI563670 & L $1999 \mathrm{~B}-17$ & China & Yes & $w x^{b}$ & $6.2 \pm 0.20$ & 76.34 & 11.22 & 3.78 & 1.75 & 1.85 & 88.3 & - \\
\hline PI563671 & L 1999B-18 & China & Yes & $w x^{\mathrm{b}}$ & $5.8 \pm 0.90$ & 72.41 & 12.40 & 3.60 & 1.98 & 1.94 & 90.3 & - \\
\hline PI586524 & IS 27929 & China & No & $w x^{\mathrm{a}}$ & $6.2 \pm 0.35$ & 69.88 & 13.53 & 5.21 & 1.86 & 2.16 & 89.6 & + \\
\hline PI586526 & IS 27931 & China & No & $w x^{\mathrm{a}}$ & $7.0 \pm 0.15$ & 69.48 & 12.40 & 5.37 & 1.75 & 1.89 & 90.6 & + \\
\hline PI586529 & IS 27935 & China & No & $w x^{\mathrm{a}}$ & $6.7 \pm 0.45$ & 66.79 & 14.29 & 5.69 & 1.55 & 1.72 & 92.2 & + \\
\hline PI455543 & ETS 3634 & Ethiopia & No & $w x^{\mathrm{a}}$ & $6.6 \pm 0.15$ & 70.76 & 13.60 & 5.35 & 1.53 & 2.01 & 89.4 & - \\
\hline PI586448 & Cody & Hungary & No & $w x^{\mathrm{a}}$ & $5.8 \pm 0.64$ & 75.19 & 12.02 & 4.81 & 1.77 & 1.96 & 89.9 & - \\
\hline PI586454 & Leoti & Hungary & No & $w x^{a}$ & $6.8 \pm 0.72$ & 67.71 & 14.17 & 5.11 & 1.80 & 2.12 & 89.1 & + \\
\hline PI217897 & 305 & Indonesia & Yes & $w x^{b}$ & $5.9 \pm 0.20$ & 68.94 & 12.02 & 5.18 & 1.61 & 1.71 & 89.9 & + \\
\hline PI234456 & Unknown & Japan & No & $w x^{\mathrm{a}}$ & $6.4 \pm 1.12$ & 71.30 & 12.15 & 4.94 & 1.58 & 1.75 & 90.2 & + \\
\hline PI82340 & Kaoliang-WX & Korea & No & $w x^{\mathrm{a}}$ & $6.5 \pm 0.30$ & 72.30 & 12.34 & 4.23 & 1.89 & 2.09 & 88.3 & + \\
\hline PI87355 & Bomususu & Korea & No & $w x^{a}$ & $6.1 \pm 0.40$ & 69.71 & 14.40 & 5.17 & 1.88 & 2.14 & 89.9 & + \\
\hline PI88004 & Susu zairai shu & Korea & No & $w x^{\mathrm{a}}$ & $6.1 \pm 0.59$ & 69.23 & 13.68 & 5.04 & 1.63 & 2.16 & 88.8 & + \\
\hline PI563015 & Kaura Mai Faran Kona & Nigeria & No & $w x^{\mathrm{a}}$ & $6.6 \pm 0.51$ & 65.36 & 15.46 & 5.64 & 1.75 & 1.93 & 88.4 & + \\
\hline PI567803 & Yungju & South Korea & No & $w x^{a}$ & $7.0 \pm 0.35$ & 67.19 & 13.51 & 5.46 & 1.57 & 2.06 & 91.7 & + \\
\hline PI567809 & Unknown & South Korea & No & $w x^{a}$ & $6.6 \pm 0.38$ & 67.55 & 14.29 & 5.27 & 1.51 & 1.82 & 90.9 & + \\
\hline PI567811 & Unknown & South Korea & No & $w x^{\mathrm{a}}$ & $7.3 \pm 0.20$ & 66.80 & 13.43 & 5.09 & 1.70 & 1.97 & 91.3 & + \\
\hline PI562758 & Basuto Red Q2-1-29 & USA & No & $w x^{\mathrm{a}}$ & $6.2 \pm 1.02$ & 72.18 & 16.75 & 4.28 & 2.03 & 2.28 & 86.0 & - \\
\hline PI563068 & IS 8303 & USA & No & $w x^{a}$ & $6.2 \pm 0.83$ & 71.53 & 14.30 & 3.00 & 2.25 & 2.06 & 88.5 & - \\
\hline \multirow[t]{2}{*}{ PI563402 } & IS 10497 & USA & No & $w x^{a}$ & $6.1 \pm 0.10$ & 69.94 & 15.04 & 3.78 & 1.94 & 2.49 & 89.6 & - \\
\hline & Ellis & USA, wild & No & $W x$ & $6.3 \pm 0.10$ & 72.86 & 13.28 & 4.46 & 1.91 & 1.71 & 90.5 & - \\
\hline
\end{tabular}

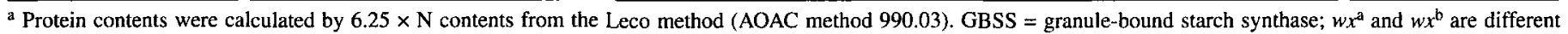
forms of the allele. 
then brought to the $100 \mathrm{~mL}$ mark with distilled water. Ethanol concentrations in the distillates were analyzed by HPLC with a Rezex RCM column (Phenomenex, Torrance, CA) and refractive index detector (Wu et al 2006).

\section{Morphological Structure of Waxy Grain Sorghum}

The microstructures of waxy sorghum kernels were examined with a scanning electron microscope (SEM) with an accelerating voltage of $5.0 \mathrm{kV}$ (S-3500N, Hitachi Science Systems, Tokyo). Samples were vacuum coated with a mixture of $60 \%$ gold and $40 \%$ palladium particles with a Desk II combined sputter coater and etch unit (Denton Vacuum, Moorestown, NJ).

\section{Single Kernel Characterization and Particle-Size Analysis}

Kernel hardness, weight, and size of waxy sorghum samples were analyzed through the single kernel characterization system (SKCS) 4100 (Perten Instruments, Springfield, IL) controlled by Microsoft Windows software SK4100. The reported data were the means of 300 kernels.

The particle size of ground sorghum flour was measured by an LS 13320 single wavelength laser-diffraction particle-size analyzer (PSA) with Tornado dry powder system (Beckman Coulter, Miami, FL). Samples were run in duplicate.

\section{Pasting Properties}

Pasting properties of the sorghum flour samples were measured with a Rapid Visco Analyzer (RVA) (RVA-3D, Newport Scientific, Warriewood, Australia). For sample preparation, $4 \mathrm{~g}$ of sorghum flour (14\% moisture basis) and distilled water (25 $\mathrm{mL}$ ) were added to an aluminum canister at room temperature. A plastic paddle was inserted into the canister and then jogged and rotated manually for about $30 \mathrm{sec}$ to break up any lumps. The paddle (with the sample canister) then was attached to the electric motor in the head of the RVA. The sample was premixed by initially running the motor at $960 \mathrm{rpm}$ for $10 \mathrm{sec}$, and then the motor was slowed to $160 \mathrm{rpm}$ for the rest of the test. The standard 23 min profile of AACC International Approved Method 76-21.01 (2010) was followed for sample testing. Each sample was analyzed in duplicate.

\section{Thermal Properties}

Differential scanning calorimetry (DSC) (Pyris 1, Perkin-Elmer, Norwalk, CT) measurement was conducted and calibrated with indium. Sorghum samples were weighed accurately $(\approx 10 \mathrm{mg})$ into stainless steel pans with a microbalance. Deionized distilled water was added carefully with a micropipette into the sample pan. The weight ratio of water to dry flour was $3: 1$. The pans were sealed and allowed to rest for about $1 \mathrm{hr}$. Samples were analyzed at heating and cooling rates of $10^{\circ} \mathrm{C} / \mathrm{min}$. The temperature regime consisted of heating from 25 to $150^{\circ} \mathrm{C}$ with an initial $1 \mathrm{~min}$ hold. Data from the DSC scans were analyzed with Pyris software 7.0 for Windows (Perkin-Elmer). Enthalpies are reported on a dry flour weight basis. Each sample was analyzed at least in duplicate.

\section{Protein Digestibility}

Protein digestibility was determined following the method of Mertz et al (1984) with modification: $200 \mathrm{mg}$ sorghum samples were suspended in $35 \mathrm{~mL}$ of pepsin solution $(1.5 \mathrm{~g}$ of enzyme $/ \mathrm{L}$ of $0.1 \mathrm{M}$ potassium phosphate buffer, $\mathrm{pH} 2.0$ ) and incubated with vigorous shaking at $37^{\circ} \mathrm{C}$. Pepsin (P-7000, Sigma-Aldrich, St. Louis, MO; activity 924 units/mg of protein) digestion was stopped by addition of $2 \mathrm{~mL}$ of $2 M \mathrm{NaOH}$ at the end of the $2 \mathrm{hr}$ digestion course. After centrifugation at 4,000 $\times g$ for $15 \mathrm{~min}$, the supernatant was discarded, and the residue was washed in $10 \mathrm{~mL}$ of $0.1 M$ phosphate buffer ( $\mathrm{pH}=2.0$ ) and centrifuged as before. After the second washing and centrifugation, the residue was frozen and then lyophilized. The freeze-dried residue was then weighed and analyzed for nitrogen content.

\section{Analytical Methods}

AOAC official methods (2000) were used to analyze sorghum flour samples for dry matter and moisture (925.10), crude protein (990.03), ash (942.05), crude fiber (962.09), and crude fat (920.39). Total starch and amylose contents were measured through colorimetric procedures (Megazyme total starch and amylose/amylopectin kits; procedures are available at http:// secure.megazyme.com/downloads/en/data/K-TSTA.pdf and http:// secure.megazyme.com/downloads/en/data/K-AMYL.pdf). The presence of amylose in the waxy sorghum kernels was also qualitatively examined through iodine-staining techniques (Pedersen et al 2004). FAN was analyzed through the European Brewery Convention method (EBC 1987) with modification. Grain sorghum flour $(150 \mathrm{mg}$ ) was mixed with $1.5 \mathrm{~mL}$ of deionized distilled water in a $2.5 \mathrm{~mL}$ microcentrifuge tube and vortexed five times in $10 \mathrm{~min}$ and then centrifuged at $12,000 \mathrm{rpm}$ for 20 min. The supernatant was then ready for FAN analysis. A tannin bleach test followed the Xiang method (2009). Glucose, glycerol, and ethanol in samples were determined by HPLC (Shimadzu Scientific Instruments, Columbia, MD) according to the method described by McGinley and Mott (2008). The column used was a Rezex ROA column (Phenomenex), and the detector was a refractive index detector (RID-10A, Shimadzu) maintained at $40^{\circ} \mathrm{C}$. The mobile phase was $5 \mathrm{~m} M$ sulfuric acid at a flow rate of 0.6 $\mathrm{mL} / \mathrm{min}$, and the oven temperature was $65^{\circ} \mathrm{C}$. HPLC data were analyzed with Shimadzu EZStart 7.4 software. Fermentation efficiency was calculated as the ratio of the actual ethanol yield (grams of ethanol determined by HPLC) to the theoretical ethanol yield $(=$ starch grams $\times 1.11 \times 0.511)$ (Yan et al 2009$)$.

\section{Statistical Analyses}

All experiments were performed at least in duplicate. The tabular results presented were the mean values of repeated experimental data. Regression analyses were conducted in Microsoft Excel with the linear regression function.

\section{RESULTS AND DISCUSSION}

As clearly indicated by the major components of the samples from proximate analysis, the waxy sorghum samples used in this project had diverse genetic backgrounds and physical and chemical properties. Normal cultivars on the market have starch content of $72-76 \%(\mathrm{db})$ and protein content of around $12 \%(\mathrm{db})$. The starch content of these samples ranged from 65 to $76 \%(\mathrm{db})$, and their protein content was $12-15.8 \%(\mathrm{db})$. Details of the proximate analysis results are listed in Table I.

\section{Effect of Starch on Ethanol Production}

Figure 1 shows correlation between total starch content and ethanol yield from fermentation of 25 waxy grain sorghum samples. Ethanol yield (gallons/bushel) was linearly correlated with total starch content $\left(R^{2}=0.7946\right)$. This result is in agreement with those reported by Wu et al (2007) and Lacerenza et al (2008). Sorghum cultivars with high starch and low protein contents are cultivars of choice for fuel ethanol production. Wu et al (2008) reported that higher starch content means higher ethanol yield, better processing efficiency, and lower amounts of residues after fermentation; therefore, total starch content of waxy grain sorghum can be a predicator of ethanol yield. Average ethanol yield from waxy grain sorghum is similar to corn (Lemuz et al 2009). Although the sorghum samples tested in this study have diverse genetic backgrounds, which translate into different starch and protein contents, the ethanol yields ranged from 2.6 to 3.0 gallons per bushel, with an average of 2.8 gallons per bushel.

Endosperm of waxy grain sorghum showed little or no sign of amylose when tested by rapid iodine-staining techniques (Pedersen et al 2004). If enough amylose is present in the grain, iodine will bind with amylose in the endosperm of a grain kernel and 
turn its color dark blue; waxy grains contain no or little amylose and will turn reddish brown (Pedersen et al 2004). The iodinestaining test showed that amylose contents were low in most waxy sorghum samples and slightly higher in a few other samples. The Megazyme amylose assay and DSC analysis results further confirmed the iodine-staining test results. All 25 tested cultivars of waxy grain sorghum had small amounts of amylose, ranging from 5.5 to $7.3 \%$. Fortunately, amylose content in waxy grain sorghum had no significant effect on ethanol yield $\left(R^{2}=\right.$ 0.1341 , Figure 1). This was probably because amylose contents in the tested samples were all very low $(<7.3 \%)$ and within a narrow range (5.5-7.3\%, Table I). The chances for such small amounts of amylose to complex with lipids in waxy grain sorghum were lower than in normal grain sorghums, which have amylose contents of 23-30\% (Wu et al 2006, 2010).

DSC results confirmed that only four (PI220636, PI217897, PI548008, and PI562758) out of the 25 tested waxy cultivars showed an amylose-lipid complex enthalpy peak at temperatures around $100^{\circ} \mathrm{C}$ (Table II). Fermentation efficiencies of those four cultivars (with amylose-lipid complex peaks) were lower than those of cultivars without amylose-lipid complex. Actually, two of these waxy sorghum samples (PI562758 and PI548008) had the lowest fermentation efficiencies among all 25 tested samples, 86.0 and $87.7 \%$, respectively; the average efficiency of all 25 samples was $89.6 \%$. Previous research conducted on different ratios of commercial amylose and amylopectin for ethanol production showed that high amylose content led to low ethanol yield (Wu et al 2006). In normal wheat, corn, and sorghum, amylose is located in the amorphous region of starch granules and
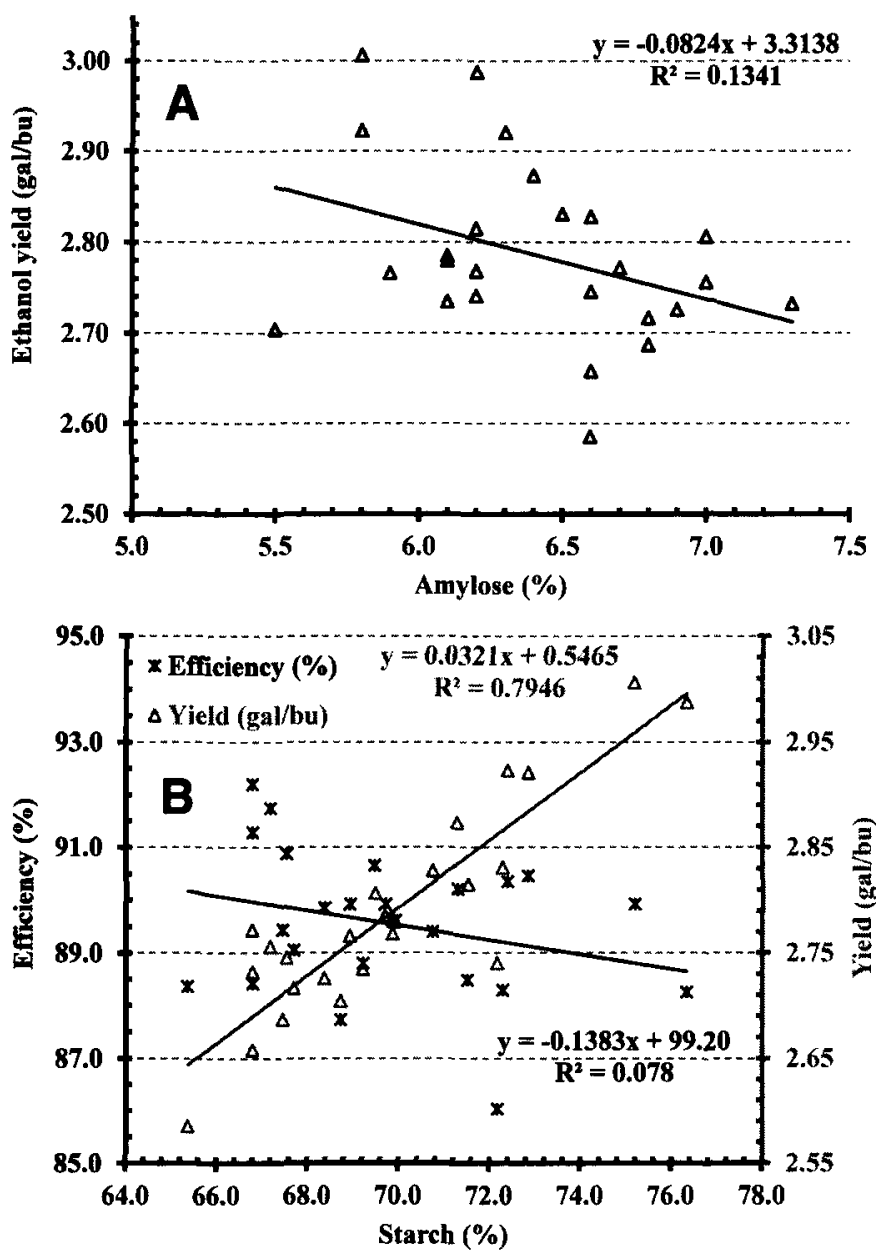

Fig. 1. Relationships between A, amylose content and ethanol yield, and B, starch content of waxy grain sorghum and fermentation efficiency and ethanol yields. amylopectin is in the crystalline region of starch granules. When amylose content is high in starch granules, amylose can readily leach out of starch granules when the granules are absorbing water. On the other hand, higher amylose content also provides increased amylose-lipid complex formation that inhibits swelling of starch granules. In waxy varieties, amylose content is low, and there is little amylose leaching out from starch granules when they are absorbing water (Sang et al 2008). Thus, amylose in waxy grain sorghum did not significantly affect starch granules among waxy varieties; nor did the small amount of amylose in waxy grain sorghum have a significant effect on the dry-grind ethanol process and the final ethanol yield. RVA pasting profiles of waxy grain sorghum flour showed a lower pasting temperature, higher peak viscosity, and lower final viscosity than for normal sorghum starch (Zhao et al 2008). The SKCS and PSA data showed that the hardness index (average of 88.6) of waxy sorghum was similar to that of normal sorghum (87.7) (Pedersen et al 1996) and significantly lower than that of corn (Abdelrahman and Hoseney 1984), and it can more easily be ground into fine particles. Lower pasting temperature, lower final viscosity, and lower hardness of waxy sorghum imply less energy consumption in the dry-grind ethanol process.

Two common phenomena were observed when waxy grain sorghum kernel was scanned with SEM (Figure 2). One was kernel texture (low magnification, $\times 500$ ), and the other was starch granule features (high magnification, $\times 5,000$ ). Figure $2 \mathrm{~A}$ shows that there are many cracks on the kernel that may render waxy grain kernels easier to grind and may generate more damaged starches in the flour. In previous research, Abdel-Aal et al (2002) reported that there were more damaged starches in waxy wheat and waxy corn flour than in those from normal wheat and corn. Waxy sorghum starches probably share the same properties with waxy wheat and waxy corn. Figure 2B shows many holes in waxy starch granules, which obviously make waxy starch granules more susceptible to enzymatic digestion because water and enzymes can more easily enter starch granules through these pores. The results agree with the conclusion drawn by Sullins and Rooney (1975), that is, waxy starch granules were more susceptible to enzymatic degradation than were nonwaxy starch granules. Sullins and Rooney (1975) also found that waxy grain sorghum had a less dense peripheral endosperm than did nonwaxy grain sorghum. The waxy sorghum flours, however, absorbed significantly more water than did normal sorghum flours, which could be explained by the presence of pores on the waxy starch granules. Wu et al (2007) reported that waxy sorghum cultivars had higher conversion efficiency in the laboratory dry-grind ethanol process than did nonwaxy cultivars because waxy starches were more easily hydrolyzed and gelatinized during the mashing process. Data from this study prompted a similar conclusion to that of Wu et al (2007).

\section{Effect of FAN on Ethanol Production}

Researchers have found that one of the factors limiting the production of high levels of ethanol by brewing yeast is nutritional deficiency (Casey and Ingledew 1986). When a nitrogen source is supplemented in the fermentation system, the nutritional supple-

TABLE II

Differential Scanning Calorimetry Properties of Waxy Grain Sorghuma

\begin{tabular}{lccccc}
\hline Temperature & $\begin{array}{c}\text { Onset } \\
\text { Temp. } \\
\left({ }^{\circ} \mathbf{C}\right)\end{array}$ & $\begin{array}{c}\text { Peak } \\
\text { Temp. } \\
\left({ }^{\circ} \mathbf{C}\right)\end{array}$ & $\begin{array}{c}\text { Conclusion } \\
\text { Temp. } \\
\left({ }^{\circ} \mathbf{C}\right)\end{array}$ & $\begin{array}{c}\text { Second } \\
\text { Peak } \\
\text { Temp. }\left({ }^{\circ} \mathbf{C}\right)\end{array}$ & $\begin{array}{c}\text { Gelatinization } \\
\text { Enthalpy } \\
(\mathbf{A H}, \mathbf{J} / \mathbf{g})\end{array}$ \\
\hline Min & 69.91 & 75.59 & 81.47 & 99.00 & 8.19 \\
Max & 73.51 & 78.13 & 94.38 & 102.6 & 11.88 \\
Mean & 71.58 & 76.54 & 84.27 & 100.1 & 9.62 \\
\hline
\end{tabular}

Values are average of two measurements. Among 25 varieties, only 4 had the second peak (amylose-lipid complex). 
ment can promote rapid fermentation to a higher ethanol level without the need to genetically improve yeast. Therefore, FAN in the original sample is crucial to yeast performance. A strong positive linear relationship between fermentation efficiency at the 30 th hr of fermentation and FAN content in the original sample was observed in this study (Figure 3), but by the end of fermentation, no linear correlation was found between FAN content in the original sample and the final fermentation efficiency. Sufficient FAN in the fermentation mash is critical to yeast cell growth and proliferation during the early stage of fermentation. The higher the FAN levels in finished mash, the faster the fermentation process. Because almost all the sugars in the tested samples were converted into ethanol, the final fermentation efficiencies among the samples at the end of fermentation were very close. Our previous research strongly supports the effects of FAN on ethanol fermentation efficiency from field-sprouted sorghum (Yan et al 2010). Casey et al (1984) made the same conclusion about the effect of FAN on fermentation efficiency of high-gravity brewing from wheat. Therefore, FAN content in a sample could be a useful indicator of a sample's performance in ethanol fermentation. Data from our previous studies (Yan et al 2009, 2010) showed similar results, which agree with results reported by several other investigators (Casey et al 1984; Lekkas et al 2005). Mullins and NeSmith (1987) studied ethanol fermentation with high-tannin sorghum and revealed that the addition of nitrogen accelerated the ethanol fermentation rate.

\section{Effect of Protein Digestibility on Ethanol Production}

Protein digestibility has been used as a quality indicator for human foods and animal feeds. A protein with high digestibility potentially has better nutritional value than those with low digestibility. The protein digestibility of sorghum has been studied extensively in vitro by using pepsin because the in vitro pepsin digestibility results correlate well with in vivo digestibility results (Maclean et al 1981), which makes sense because humans and animals produce pepsin in their digestive tracts. In contrast, yeast does not produce any exoprotease for ethanol fermentation. However, Wang et al (2008) reported a strong linear correlation between protein digestibility of some normal grain sorghum samples and their fermentation efficiency in ethanol production. The same protein digestibility methodology was applied in this study regarding waxy grain sorghums. The ethanol fermentation data on waxy sorghum samples showed that fermentation efficiency in the laboratory dry-grind process did not show any linear correlation with protein digestibility $\left(R^{2}=0.0093\right.$ ) (Figure 4). The presence of tannins in some of the sorghum cultivars used in this study could be the main cause for such divergence. Tannins have been related to lowering starch digestibility by inactivating amylases (Davis and Hoseney 1979). The same phenomenon of enzyme inactivation may be applied to pepsin here in the protein digestibility test. Protein-hydrolyzing activity of pepsin in the digestibil-

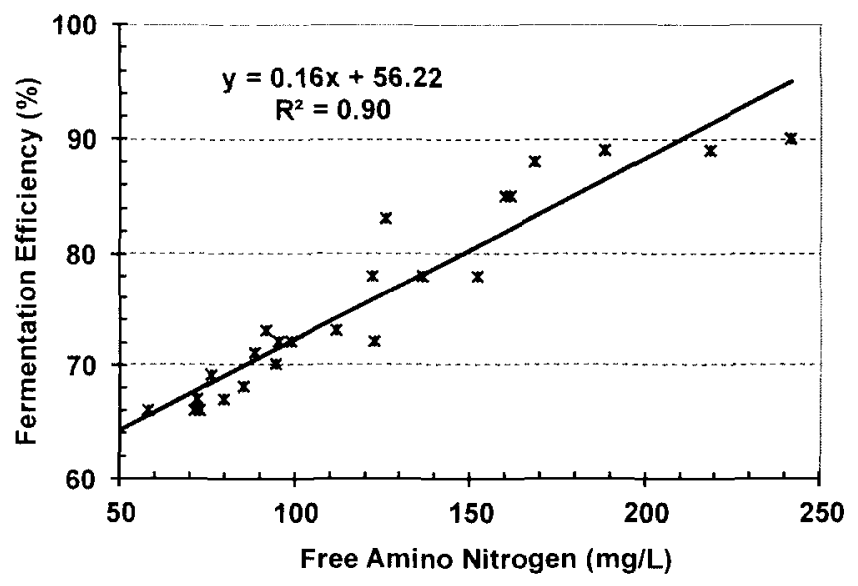

Fig. 3. Linear correlation between free amino nitrogen content $(\mathrm{mg} / \mathrm{L})$ in original sorghum samples and fermentation efficiency of waxy grain sorghum at the 30 th hr of fermentation.

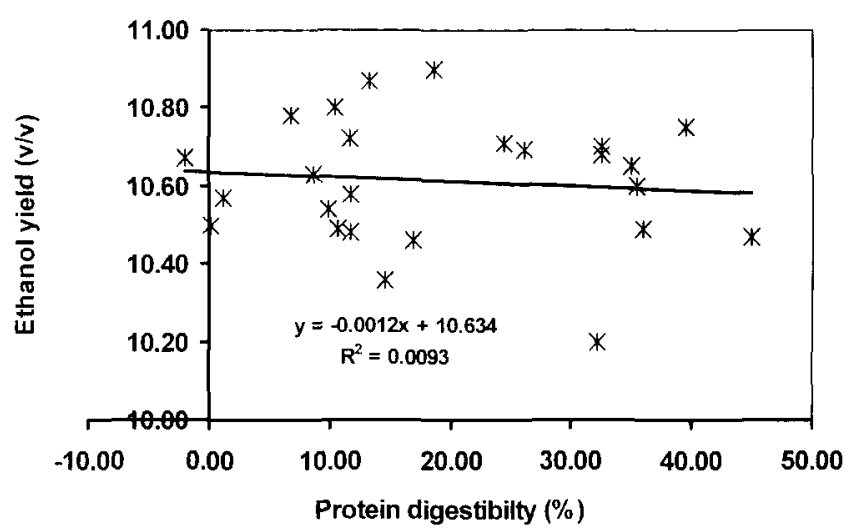

Fig. 4. Relationship between ethanol fermentation efficiency and protein digestibility of tested sorghum samples.
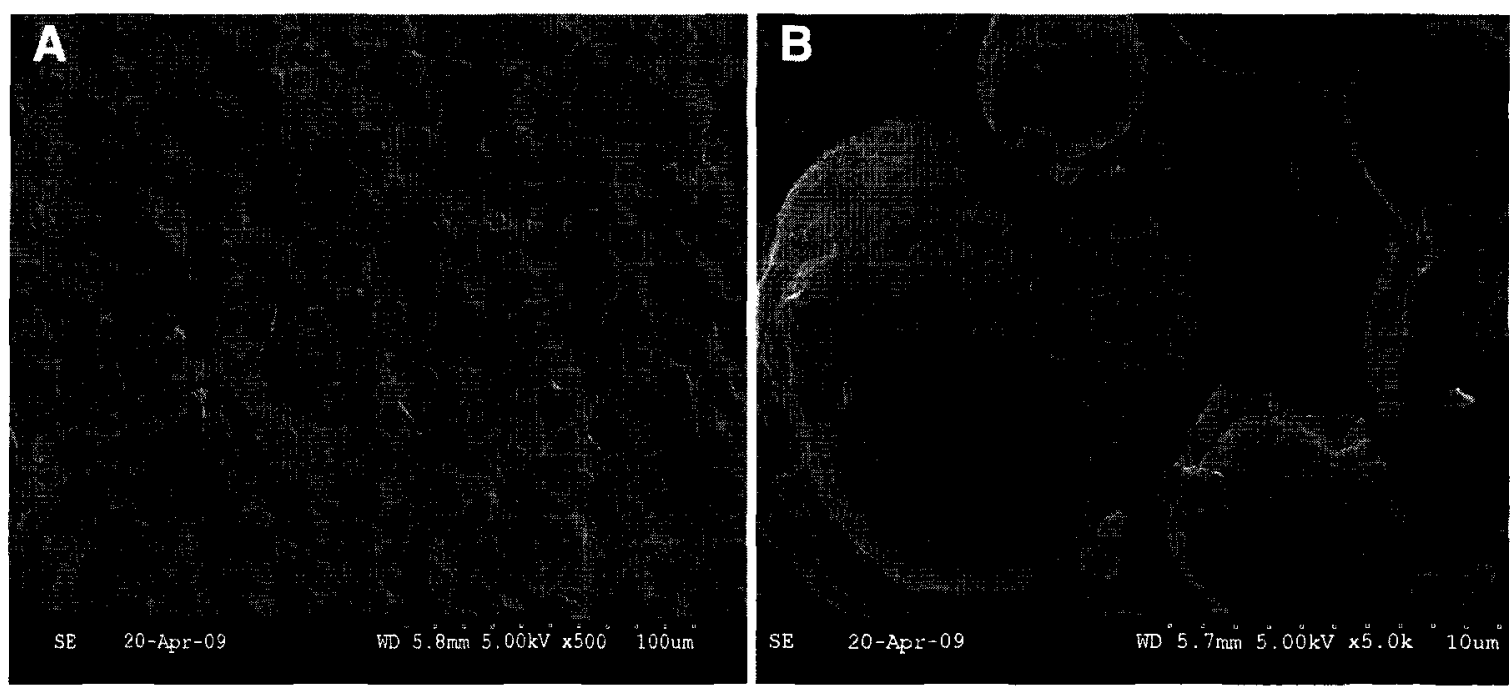

Fig. 2. A, scanning electron microscopy (SEM) image of waxy grain sorghum endosperm showing cracks $(\times 500)$; B, SEM image of starch granules showing many fine pores $(\times 5,000)$. 
ity test could have been inhibited by the tannins in the tested samples. A qualitative tannin test (bleach test) revealed that 16 of the 25 tested waxy cultivars contained tannins. Although yeast itself does not produce exoproteases during the normal fermentation process, addition of proteinases during mashing or the SSF process nevertheless can generate favorable results (increasing the fermentation rate, cell tolerance to ethanol, and final ethanol yield). Hydrolysis of proteins in the raw materials might help with the release of more starch granules from the protein matrix and increase FAN content in the mash (Thomas and Ingledew 1990; Pérez-Carrillo et al 2008), which will facilitate yeast growth and increase the ethanol fermentation rate and efficiency.

\section{Effect of Tannins on Ethanol Production}

Sorghum tannins have attracted great attention from a number of researchers because of their effects on product yield and quality, processing properties, starch and protein digestibility, and health (Beta et al 2000; Wang et al 2008; Dlamini et al 2009; Serrano et al 2009). Wu et al (2007) claimed that sorghum tannins retarded the liquefaction process during mashing and resulted in high-viscosity mash, slow starch-to-glucose conversion, and lower conversion efficiency. The data showed that ethanol yields and fermentation efficiencies of waxy sorghums containing tannins were 2-3\% lower than those of waxy sorghums without tannins. Mullins and NeSmith (1986) studied ethanol fermentation from bird-resistant and non-bird-resistant grain sorghum and reported that high tannin levels greatly reduced the rate of ethanol production. Evidently, the rate of ethanol production was much slower from bird-resistant grain sorghum than from non-birdresistant grain sorghum because tannins partially inhibited the activities of amylases and glucose was generated at a much slower rate in the bird-resistant grain sorghum mash. On the other hand, tannins could cause sorghum protein cross-linking during heating or cooking, prevent starch granules from absorbing water, and prevent enzymatic degradation (Duodu et al 2003).

\section{Chemical Composition of Distillers Dried Grains with Solubles}

Distillers dried grains with solubles (DDGS) is a by-product from ethanol production and is typically used as animal feed. The nutritional composition is critical to buyers. Table III shows the major components of DDGS from waxy and nonwaxy grain sorghum varieties (Wu and Sexson 1984; Saunders and Rosentrater 2009; Stein and Shurson 2009; Urriola et al 2009). Residual starch contents in industrial corn or sorghum DDGS are around 5\% (Saunders and Rosentrater 2009; Stein and Shurson 2009). DDGS from normal grain sorghums following a laboratory drygrind ethanol process had $1-2 \%$ starch. The residual starch contents in DDGS from waxy grain sorghum samples in this study were much lower, only around $0.5 \%$, which means that starch in waxy grain sorghum was more efficiently used for ethanol production than that in normal grain sorghum. Because waxy sorghum generally has higher protein content than corn and normal sorghum and because starch in waxy sorghum is more efficiently utilized in ethanol production, DDGS from waxy sorghum will have higher crude protein, crude fat, and ash contents than will DDGS from normal grains (Saunders and Rosentrater 2009). Because the major market for DDGS right now is the animal feed industry, higher protein content means better quality, broader application, and possibly better market price.

\section{TABLE III}

Chemical Composition of Distillers Dried Grain with Solubles

from Waxy and Nonwaxy Grain Sorghum Varieties $(\%, \mathrm{db})$

\begin{tabular}{llcccc}
\hline Variety & Starch & Protein & Lipids & Fiber & Ash \\
\hline Waxy & $0.44-0.72$ & $33.3-42.0$ & $9.5-16.3$ & $3.2-6.0$ & $5.8-7.9$ \\
Nonwaxy & $2.0-5.7$ & $30.3-36.6$ & $10.8-12.5$ & $7.5-11.6$ & $2.1-5.3$ \\
\hline
\end{tabular}

\section{CONCLUSION}

This ethanol-production study on waxy grain sorghum varieties demonstrated that ethanol yields from waxy sorghums were essentially proportional to their starch contents. Amylose contents in the tested waxy sorghum samples were in a low, narrow range and had little effect on ethanol yield and fermentation efficiency. Ethanol yields from the tested waxy grain sorghums were around 2.8 gallons/bushel, which is similar to that reported for corn. The fermentation efficiency was greatly affected by FAN content in waxy sorghums, which had a strong positive linear correlation with early-stage (the first 30-36 hr) fermentation efficiency. Tannins were found in most of the tested waxy sorghums and had negative effects on ethanol yield and fermentation efficiency. DDGS from waxy sorghums has higher protein but lower starch contents, implying better quality as animal feed.

\section{ACKNOWLEDGMENTS}

This project was funded by the Kansas Grain Sorghum Commission and the Center for Sorghum Improvement, Kansas State University. Contribution number 11-327-J from the Kansas Agricultural Experiment Station.

\section{LITERATURE CITED}

AACC International. 2010. Approved Methods of Analysis, 11th Ed. Method 76-21.01. Available online only. AACC International: St. Paul, MN.

Abdel-Aal, E.-S. M., Hucl, P., Chibbar, R. N., Han, H. L., and Demeke, T. 2002. Physicochemical and structural characteristics of flours and starches from waxy and nonwaxy wheats. Cereal Chem. 79:458-464.

Abdelrahman, A. A., and Hoseney, R. C. 1984. Basis for hardness in pearl millet, grain sorghum, and corn. Cereal Chem. 61:232-235.

AOAC International. 2000. Official Methods of Analysis, 16th Ed. Methods $920.39,925.10,942.05,962.09$, and 990.03. AOAC International: Gaithersburg, MS.

Beta, T., Rooney, L. W., and Taylor, J. R. N. 2000. Effect of chemical conditioning on the milling of high-tannin sorghum. J. Sci. Food Agric. 80:2216-2222.

Casey, G. P., and Ingledew, W. M. 1986. Ethanol tolerance in yeasts. Crit. Rev. Microbiol. 13:219-280.

Casey, G. P., Magnus, C. A., and Ingledew, W. M. 1984. High-gravity brewing: Effects of nutrition on yeast composition, fermentative ability, and alcohol production. Appl. Environ. Microbiol. 83:639-646.

Davis, A. B., and Hoseney, R. C. 1979. Grain sorghum condensed tannins. I. Isolation, estimation, and selective adsorption by starch. Cereal Chem. 56:310-314.

Dlamini, N. R., Dykes, L., Rooney, L. W., Waniska, R. D., and Taylor, J. R. N. 2009. Condensed tannins in traditional wet-cooked and modern extrusion-cooked sorghum porridges. Cereal Chem. 86:191-196.

Duodu, K. G., Taylor, J. R. N., Belton, P. S., and Hamaker, B. R. 2003. Factors affecting sorghum protein digestibility. J. Cereal Sci. 38: 117-131.

European Brewery Convention (EBC). 1987. Free amino nitrogen-ninhydrin colorimetric method. Pages E141-142 in: Analytica-EBC, 4th Ed. Brauerei- und Getränke-Rundschau: Zurich.

Farrell, A. E., Plevin, R. J., Turner, B. T., Jones, A. D., O'Hare, M., and Kammen, D. M. 2006. Ethanol can contribute to energy and environmental goals. Science 311:506-508.

Kubecka, B. 2011. Sorghum plays role in ethanol's impact. Ethanol Prod. Mag. Feb. issue, p. 18.

Lacerenza, J. A., Martin, J. M., Talbert, L. E., Lanning, S. P., and Giroux, M. J. 2008. Relationship of ethanol yield to agronomic and seed quality characteristics of small grains. Cereal Chem. 85:322-328.

Lekkas, C., Stewart, G. G., Hill, A., Taidi, B., and Hodgson, J. 2005. The importance of free amino nitrogen in wort and beer. Tech. Q. Master Brew. Assoc. Am. 42:113-116.

Lemuz, C. R., Dien, B. S., Singh, V., McKinney, J., Tumbleson, M. E., and Rausch, K. D. 2009. Development of an ethanol yield procedure for dry-grind corn processing. Cereal Chem. 86:355-360.

Mace, E., and Jordan, D. 2010. Location of major effect genes in sorghum (Sorghum bicolor (L.) Moench). Theor. Appl. Genetics 121: 1339-1356. 
Maclean, W. C., De Romana, G. L., Placko, R. P., and Graham, G. G. 1981. Protein quality and digestibility of sorghum in pre-school children: Balance studies and plasma free amino acids. J. Nutr. 111:19281936.

McGinley, M., and Mott, J. 2008. Bioethanol production monitoring using ion exclusion HPLC with Rezex ${ }^{\mathrm{TM}}$ ROA column. Phenomenex Application Note TN-1043. Available at www.brechbuehler.ch/ fileadmin/redacteur/pdf/services/app-support/tech-chem_and_packaging/ TN1043_bioethanol_monitoring_using_Rezex_ROA_LC.pdf.

Mertz, E. T., Hassen, M. M., Cairns-Whittern, C., Kirleis, A. W., Tu, L., and Axtell, J. D. 1984. Pepsin digestibility of proteins in sorghum and other major cereals. Proc. Natl. Acad. Sci. USA. 81:1-2.

Mullins, J. T., and NeSmith, C. 1986. Ethanol production from bird-resistant and non-bird-resistant grain sorghum. Pages 541-550 in: Biomass Energy Development. W. H. Smith, ed. Plenum Press: New York.

Mullins, J. T., and NeSmith, C. 1987. Acceleration of the rate of ethanol fermentation by addition of nitrogen in high tannin grain sorghum. Biotechnol. Bioeng. 30:1073-1076.

Owuama, C. I. 1997. Sorghum: A cereal with lager beer brewing potential. World J. Microbiol. Biotechnol. 13:253-260.

Pedersen, J. F., Martin, C. R., Felker, F. C., and Steele, J. L. 1996. Application of the single kernel wheat characterization technology to sorghum grain. Cereal Chem. 73:421-423.

Pedersen, J. F., Bean, S. R., Funnell, D. L., and Graybosch, R. A. 2004. Rapid iodine staining techniques for identifying the waxy phenotype in sorghum grain and waxy genotype in sorghum pollen. Crop Sci. 44: 764-767.

Pedersen, J. F., Graybosch, R. A., and Funnell, D. L. 2007. Occurrence of the waxy alleles $w x^{a}$ and $w x^{b}$ in waxy sorghum plant introductions and their effect on starch thermal properties. Crop Sci. 47:1927-1933.

Pérez-Carrillo, E., and Serna-Saldívar, S. O. 2007. Effect of protease treatment before hydrolysis with $\alpha$-amylase on the rate of starch and protein hydrolysis of maize, whole sorghum, and decorticated sorghum. Cereal Chem. 84:607-613.

Pérez-Carrillo, E., Serna-Saldívar, S. O., Alvarez, M. M., and CortesCallejas, M. L. 2008. Effect of sorghum decortication and use of protease before liquefaction with thermoresistant $\alpha$-amylase on efficiency of bioethanol production. Cereal Chem. 85:792-798.

Pickercll, A. T. W. 1986. The influence of free alpha-amino nitrogen in sorghum beer fermentations. J. Inst. Brew. 92:568-571.

Renewable Fuels Association (RFA). 2007. Building new horizons: 2007 ethanol industry outlook. Available at www.ethanolrfa.org/pages/ annual-industry-outlook. Accessed on March 25, 2011.

Rooney, L. W., and Serna-Saldivar, S. O. 2000. Sorghum. Pages 149-176 in: Handbook of Cereal Science and Technology, 2nd Ed. K. Kulp and J. G. Ponte, Jr., eds. Marcel Dekker: New York.

Rooney, W. L., Blumenthal, J., Bean, B., and Mullet, J. E. 2007. Designing sorghum as a dedicated bioenergy feedstock. Biofuels Bioprod. Bioref. 1:147-157.

Sang, Y., Bean, S., Seib, P. A., Pedersen, J., Shi, Y.-C. 2008. Structure and functional properties of sorghum starches differing in amylose content. J. Agric. Food Chem. 56:6680-6685.

Sarath, G., Mitchell, R. B., Sattler, S. E., Funnell, D., Pedersen, J. F., Graybosch, R. A., and Vogel, K. P. 2008. Opportunities and roadblocks in utilizing forages and small grains for liquid fuels. J. Ind. Microbiol. Biotechnol. 35:343-354.

Saunders, J. A., and Rosentrater, K. A. 2009. Survey of US fuel ethanol plants. Bioresour. Technol. 100:3277-3284.

Schober, T. J., Messerschmidt, M., Bean, S. R., Park, S.-H., and Arendt, E. K. 2005. Gluten-free bread from sorghum: Quality differences among hybrids. Cereal Chem. 82:394-404.

Serrano, J., Puupponen-Pimia, R., Dauer, A., Aura, A.-M., and SauraCalixto, F. 2009. Tannins: Current knowledge of food sources, intake, bioavailability and biological effects. Mol. Nutr. Food Res. 53(S2): S310-S329.

Stein, H. H. and Shurson, G. C. 2009. The use and application of distillers dried grains with solubles in swine diets. J. Anim. Sci.87:1292-1303.

Sullins, R. D., and Rooney, L. W. 1975. Light and scanning electron microscopic studies of waxy and nonwaxy endosperm sorghum varieties. Cereal Chem. 52:361-366.

Taylor, J. R. N., and Boyd, H. K. 1986. Free $\alpha$-amino nitrogen production in sorghum beer mashing. J. Sci. Food Agric. 37:1 109-1117.

Taylor, J. R. N., Schober, T. J., and Bean, S. R. 2006. Novel food and non-food uses for sorghum and millets. J. Cereal Sci. 44:252-271.

Thomas, K. C., and Ingledew, W. M. 1990. Fuel alcohol production: Effects of free amino nitrogen on fermentation of very-high-gravity wheat mashes. Appl. Environ. Microbiol. 56:2046-2050.

Urriola, P. E., Hoehler, D., Pedersen, C., Stein, H. H., and Shurson, G. C. 2009. Amino acid digestibility of distillers dried grains with solubles, produced from sorghum, a sorghum-corn blend, and corn fed to growing pigs. J. Anim. Sci. 87:2574-2580.

USDA-NASS. 2011. Crop Production 2010 Summary. Rep. No. ISSN 10577823. U.S. Department of Agriculture, National Agricultural Statistics Service: Washington, DC. Available at http://usda.mannlib.cornell.edu/ usda/current/CropProdSu/CropProdSu-01-12-2011_new_format.pdf. Accessed on April 12, 2011.

Wang, D., Bean, S., McLaren, J., Seib, P. A., Madl, R., Tuinstra, M., Shi, Y.-C., Lenz, M., Wu, X., and Zhao, R. 2008. Grain sorghum is a viable feedstock for ethanol production. J. Ind. Microbiol. Biotechnol. 35: 313-320.

Wang, P., Singh, V., Xu, L., Johnston, D. B., Rausch, K. D., and Tumbleson, M. E. 2005. Comparison of enzymatic (e-mill) and conventional dry-grind corn processes using a granular starch hydrolyzing enzyme. Cereal Chem. 82:734-738.

Wu, X., Zhao, R., Wang, D., Bean, S. R., Seib, P. A., Tuinstra, M. R., Campbell, M., and O'Brien, A. 2006. Effects of amylose, corn protein, and corn fiber contents on production of ethanol from starch-rich media. Cereal Chem. 83:569-575.

Wu, X., Zhao, R., Bean, S. R., Seib, P. A., McLaren, J. S., Madl, R. L., Tuinstra, M., Lenz, M. C., and Wang, D. 2007. Factors impacting ethanol production from grain sorghum in the dry-grind process. Cereal Chem. 84: 130-136.

Wu, X., Zhao, R., Liu, L., Bean, S., Seib, P. A., McLaren, J., Madl, R., Tuinstra, M., Lenz, M., and Wang, D. 2008. Effects of growing location and irrigation on attributes and ethanol yields of selected grain sorghums. Cereal Chem. 85:495-501.

Wu, X., Jampala, B., Robbins, A., Hays, D., Yan, S., Xu, F., Rooney, W., Peterson, G., Shi, Y.-C., and Wang, D. 2010. Ethanol fermentation performance of grain sorghums (Sorghum bicolor) with modified endosperm matrices. J. Agric. Food Chem. 58:9556-9562.

Wu, Y. V. 1989. Protein-rich residue from ethanolic fermentation of highlysine, dent, waxy, and white corn varieties. Cereal Chem. 66:506-509.

Wu, Y. V., and Sexson, K. R. 1984. Fractionation and characterization of protein-rich material from sorghum alcohol distillation. Cereal Chem. 61:388-391.

Xiang, W. 2009. Identification of two interacting quantitative trait loci controlling for condensed tannin in sorghum grain and grain quality analysis of a sorghum diverse collection. Master's thesis. Kansas State University: Manhattan, KS. pp. 1-88.

Yan, S., Wu, X., MacRitchie, F., and Wang, D. 2009. Germinationimproved ethanol fermentation performance of high-tannin sorghum in a laboratory dry-grind process. Cereal Chem. 86:597-600.

Yan, S., Wu, X., Dahlberg, J., Bean, S. R., MacRitchie, F., Wilson, J., and Wang, D. 2010. Properties of field-sprouted sorghum and its performance in ethanol production. J. Cereal Sci. 51:374-380.

Zhao, R., Bean, S. R., Ioerger, B. P., Wang, D., and Boyle, D. L. 2008. Impact of mashing on sorghum proteins and its relationship to ethanol fermentation. J. Agric. Food Chem. 56:946-953.

Zhao, R., Wu, X., Seabourn, B. W., Bean, S. R., Guan, L., Shi, Y.-C., Wilson, J. D., Madl, R., and Wang, D. 2009. Comparison of waxy vs. nonwaxy wheats in fuel ethanol fermentation. Cereal Chem. 86: 145-156.

[Received April 28, 2011. Accepted October 24, 2011.] 